\title{
PARTISIPASI ISTRI NELAYAN PADA KEGIATAN EKONOMI PRODUKTIF DI KECAMATAN AMPENAN
}

\author{
FISHERMAN WIFE PARTICIPATION IN PRODUCTIVE \\ ECONOMIC ACTIVITIES IN AMPENAN DISTRICT
}

\author{
Camila, Anwar, dan Sri Supartiningsih \\ Program Studi Agribisnis Fakultas Pertanian Universitas Mataram
}

\begin{abstract}
ABSTRAK
Penelitian ini bertujuan untuk: mengindentifikasi jenis kegiatan ekonomi yang dilakukan oleh istri nelayan, mengetahui partisipasi istri nelayan pada kegiatan ekonomi, dan menganalisis kontribusi pendapatan istri nelayan terhadap pendapatan rumahtangga nelayan.

Penelitian ini menggunakan metode deskriptif dan teknik pengumpulan data menggunakan teknik survei dengan unit analisis rumahtangga nelayan di pesisir Pantai Ampenan. Penentuan daerah sampel dengan tehnik purposive sampling yaitu Kelurahan Bintaro, yang meliputi Lingkungan Bugis, Pondok Perasi dan Bintaro. Analisis data yang digunakan adalah Analisis Biaya dan Pendapatan, Partisipasi dan Kontribusi.

Hasil penelitian menunjukkan bahwa: jenis kegiatan ekonomi produktif yang dilakukan istri nelayan meliputi: pedagang ikan, sembako, serabi, nasi, jajan dan pedagang sayur; buruh cuci, buruh pindang, pembantu rumahtangga, pengasuh anak, penjaga toko, dan karyawan loundry. Istri nelayan memanfaatkan peluang bekerja pada kegiatan ekonomi produktif dengan rata-rata partisipasi 261,31 HKO (71,59\%) per tahun. Rata-rata pendapatan rumahtangga nelayan sebesar Rp 162.657 .038 per tahun dengan rata-rata kontribusi pendapatan perempuan sebesar $6,72 \%$ dari total pendapatan rumahtangga.

Disarankan untuk meningkatkan pendapatan istri nelayan khususnya di Kecamatan Ampenan kepada pemerintah melalui satuan kerja terkait sehingga dapat meningkatkan partisipasi istri nelayan pada berbagai kegiatan ekonomi produktif.
\end{abstract}

Kata kunci: partisipasi, kontribusi, istri nelayan 


\begin{abstract}
This study aims to: identify the types of economic activities carried out by fishermen's wives, determine the participation of fishermen's wives in economic activities, and analyze the contribution of fishermen's wives' income to fishermen's household income.

This study uses descriptive methods and data collection techniques using survey techniques with fishermen household analysis units on the coast of Ampenan Beach. The determination of the sample area using purposive sampling technique, namely Bintaro Village, which includes Bugis, Pondok Perasi and Bintaro neighborhoods. The data analysis used is Cost and Income Analysis, Participation and Contribution.

The results showed that: the types of productive economic activities carried out by fishermen's wives include: fish, groceries, pancakes, rice, snacks and vegetable traders; laundry workers, pindang workers, domestic helpers, babysitters, shopkeepers, and loundry employees. Fishermen's wives take advantage of the opportunity to work in productive economic activities with an average participation of $261.31 \mathrm{HKO}(71.59 \%)$ per year. The average household income of fishermen is IDR $162,657,038$ per year with an average contribution of women's income of $6.72 \%$ of the total household income.

It is recommended to increase the income of fishermen's wives, especially in Ampenan District, to the government through related work units so that they can increase the participation of fishermen's wives in various productive economic activities.
\end{abstract}

Keywords: participation, contribution, fishermen's wife 


\section{PENDAHULUAN}

Nusa Tenggara Barat (NTB) merupakan salah satu provinsi yang memiliki potensi maritim yang cukup besar. Secara geografis NTB terdiri dari dua pulau utama, yaitu Pulau Lombok dan Pulau Sumbawa dan 278 buah pulau-pulau kecil. Luas wilayah laut mencapai $29.159,9 \mathrm{Km}^{2}$, jauh lebih luas dibandingkan wilayah daratan yang mencapai 20.152,15 $\mathrm{Km}^{2}$ atau 59\% dari luas Provinsi NTB. Potensi kelautan ini sekaligus berfungsi sebagai proyek wisata potensial. Mata pencaharian sebagian besar penduduk di Kecamatan Ampenan yaitu berprofesi sebagai nelayan dan memperoleh pendapatan relatif rendah. Oleh karena itu istri nelayan berkontribusi dengan cara mencari pekerjaan lain untuk membantu memperoleh penghasilan tambahan.

Pada masyarakat nelayan, istri nelayan tidak banyak terlibat dalam penangkapan ikan. Tetapi berkontribusi dalam berbagai kegiatan ekonomi, yaitu berfungsi sebagai kepala rumah tangga, karena suami biasanya mencari nafkah ikan di luar dalam tempo relatif lama. Istri nelayan menggantikan peranan suaminya, dan sekaligus berperan dalam usaha pemenuhan kebutuhan sehari-hari. Peranan istri nelayan tersebut, menunjukkan bahwa sumberdaya pribadi yang disumbangkan istri nelayan dalam rumah tangganya relatif besar, yaitu berupa keterampilan dan tenaga (Kayy, 1999).

Bagi istri nelayan yang tinggal di daerah tertinggal dan berekonomi miskin peran ganda bukanlah sesuatu hal yang baru. Bagi para istri nelayan peran ganda telah ditanamkan oleh para orang tua sejak masih berusia muda. Peran ini bukan untuk meningkatkan karir tetapi semata-mata untuk kelangsungan hidup mereka dan meningkatkan perekonomian yang tentunya hal tersebut diikuti dengan adanya akses untuk memanfaatkan peluang disekitarnya. Keikutsertaan istri nelayan pada kegiatan produktif sangat ditentukan oleh akses atau peluang yang ada, tentunya peluang ini yang mempengaruhi besarnya pendapatan karena meningkatkan partisipasi (Soetrisno, 1997).

Peran ganda yang diperankan oleh ibu rumah tangga nelayan di pesisir Pantai Ampenan yang ikut serta dalam pemenuhan kebutuhan ekonomi keluarga dan juga pengurus rumah tangga menarik untuk dikaji dan dideskripsikan. Bagaimana mereka mengalokasikan waktunya agar tetap seimbang dan hasil yang mencapai optimal, antara mengurus pekerjaan rumah tangga dan membantu mencari nafkah tambahan.

Keikutsertaan istri nelayan di Kecamatan Ampenan dalam mencari pekerjaan untuk memperoleh penghasilan tambahan ditentukan oleh adanya partisipasi dalam kegiatan ekonomi produktif. Oleh karena itu dilakukan penelitian dengan judul "Partisipasi Istri Nelayan pada Kegiatan Ekonomi Produktif di Kecamatan Ampenan".

Penelitian ini bertujuan untuk: mengindentifikasi jenis kegiatan ekonomi yang dilakukan oleh isri nelayan, mengetahui partisipasi istri nelayan pada kegiatan ekonomi, dan menganalisis kontribusi pendapatan istri nelayan terhadap pendapatan rumahtangga nelayan. 


\section{METODOLOGI PENELITIAN}

Metode yang digunakan dalam penelitian ini adalah metode deskriptif yaitu suatu metode dalam meneliti status sekelompok manusia,suatu obyek, suatu set kondisi, suatu sistem pemikiran ataupun suatu kelas peristiwa pada masa sekarang. Tujuan dari penelitian deskriptif ini adalah untuk membuat deskripsi,gambaran atau lukisan secara sistematis,faktual dan akurat mengenai fakta-fakta, sifat-sifat serta perubahan antara fenomena yang diselidiki (Nazir, 2005).

Penelitian ini dilaksanakan di Kecamatan Ampenan. Kecamatan Ampenan terdiri dari 10 kelurahan, yaitu: Kelurahan Taman Sari, Kelurahan Ampenan Selatan, Kelurahan Banjar, Kelurahan Ampenan Tengah, Kelurahan Bintaro, Kelurahan Dayan Peken, Kelurahan Ampenan Utara, Kelurahan Pejeruk, Kelurahan Kebon Sari, dan Kelurahan Pejarakan Karya. Dari 10 kelurahan tersebut, terdapat 4 kelurahan yang merupakan daerah pesisir, yaitu Kelurahan Ampenan Selatan, Banjar, Ampenan Tengah dan Bintaro. Dari empat kelurahan tersebut, ditentukan Kelurahan Bintaro sebagai daerah sampel penelitian secara "purposive sampling" atas dasar pertimbangan kelurahan tersebut berada di pesisir Pantai Ampenan dan memiliki warga yang berprofesi sebagai nelayan terbanyak diantara empat kelurahan tersebut.

Responden dalam penelitian inin adalah istri nelayan. Dari kelurahan terpilih (Kelurahan Bintaro) terdapat 3 lingkungan yaitu Lingkungan Bugis, Pondok Perasi dan Bintaro Jaya. Jumlah responden ditentukan secara "quota sampling” sebanyak 30 responden yang terdistribusi disetiap lingkungan masing-masing 10 responden. Selanjutnya, untuk mendapatkan responden yang diwawancarai dilakukan secara accidental sampling.

\section{Analisis Data}

1) Untuk mengetahui kegiatan ekonomi apa saja yang dilakukan oleh para ibu rumah tangga nelayan di pesisir Pantai Ampenan menggunakan tabulasi/analisis deskriptif, yaitu data yang diperoleh dari responden disajikan dalam bentuk tabel atau diformulasikan yang sesuai, selanjutnya diinterpretasikan dan disimpulkan.

2) Untuk mengetahui besar pendapatan menurut Boediono dalam Gusmanir (2013) yang diperoleh pada kegiatan ekonomi tersebut, yaitu:

$$
\text { I }=\text { TR-TC }
$$

Keterangan:

$$
\begin{aligned}
& \mathrm{I}=\text { Pendapatan (Income) } \\
& \mathrm{TR}=\text { Total penerimaan (Total Revenue) } \\
& \mathrm{TC}=\text { Total biaya }(\text { Total Cost })
\end{aligned}
$$

3) Untuk menganalisa pendapatan rumahtangga nelayan dilakukan dengan menghitung pendapatan yang diperoleh dari semua anggota keluarga produktif yang berasal dari berbagai kegiatan produktif, dengan formula (Soekartawi,1995) sebagai berikut : 
$\mathbf{P d}_{\mathrm{i}}=\mathrm{TR}_{\mathrm{i}}-\mathbf{T C}_{\mathrm{i}}$

Keterangan:

$\mathrm{Pd}_{\mathrm{i}}=$ Pendapatan ibu rumah tangga nelayan dan anggota keluarga lainnya pada kegiatan produktif

$\mathrm{TR}_{\mathrm{i}}=$ Total penerimaan

$\mathrm{TC}_{\mathrm{i}}=$ Total biaya

4) Untuk mengetahui seberapa besar kontribusi pendapatan ibu rumah tangga nelayan dari kegiatan ekonomi tersebut terhadap pendapatan keluarga,dihitung dengan rumus Handayanin dan Gusmaniar (2013) :

$$
\mathbf{P}=\frac{\mathbf{Q x}}{\mathbf{Q y}} \boldsymbol{x} 100 \%
$$

Keterangan:

$\mathrm{P}=$ Kontribusi pendapatan ibu rumah tangga dari kegiatan ekonomi

Qx = Pendapatan ibu rumah tangga nelayan dari kegiatan ekonomi

Qy = Pendapatan rumah tangga nelayan

5) Untuk mengetahui curahan waktu kerja ibu rumah tangga nelayan untuk kegiatan ekonomi di pesisir pantai Ampenan dengan jumlah jam kerja yang digunakan dalam satuan hari kerja (hari).

\section{HASIL DAN PEMBAHASAN}

Karakteristik responden meliputi umur, tingkat pendidikan, jumlah tanggungan keluarga, pengalaman usaha dan bekerja, secara rinci diuraikan berikut.

\section{Umur Responden}

Umur responden merupakan salah satu faktor yang mempengaruhi kelancaranuntuk melaksakan suatu fasilitas. Umur dapat mempengaruhi kemampuan fisik seseorang dalam bekerja, cara berfikir dan keinginan untuk menerapkan ide-ide baru. Selain itu, juga mempengaruhi kematangan psikologi yaitu tingkat rasionalitas dan emosional dalam mengambil keputusan.

Hasil penelitian menunjukkan rata-rata umur responden 36 tahun, berkisar 24 sampai 54. Semua responden berada pada kisaran umur produktif. Menurut BPSStatistik Indonesia (2020), bahwa umur produktif adalah pada kelompok umur 15-64 tahun, sedangkan usia tidak produktif adalah usia di bawah usia 15 tahun dan 65 tahun ke atas.

\section{Tingkat Pendidikan}

Tingkat pendidikan formal merupakan salah satu faktor penting yang menentukan kualitas sumberdaya manusia di suatu wilayah. Demikian juga tingkat pendidikan formal yang dimiliki nelayan responden tentu saja memberi pengaruh 
terhadap kemampuan nelayan melakukan pengelolaan usahanya. Idealnya, semakin tinggi tingkat pendidikan formal seorang maka akan semakin baik pula pola berpikirnya sehingga mampu berpikir lebih rasional dibandingkan yang memiliki tingkat pendidikan formal yang lebih rendah.

Tabel 1. Sebaran Responden Berdasarkan Tingkat Pendidikan Formal Nelayan di Kecamatan Ampenan, Tahun 2019

\begin{tabular}{llcc}
\hline No. & Tingkat Pendidikan Formal & $\begin{array}{c}\text { Jumlah Responden } \\
\text { (orang) }\end{array}$ & $\begin{array}{c}\text { Persentase } \\
(\%)\end{array}$ \\
\hline 1 & Tidak Sekolah & 2 & 6,67 \\
2 & Tidak Tamat SD & 1 & 3,33 \\
3 & Tamat SD & 17 & 56,67 \\
4 & Tidak Tamat SMP & 3 & 10,00 \\
5 & Tamat SMP & 5 & 16,67 \\
6 & Tidak Tamat SMA & 1 & 3,33 \\
7 & Tamat SMA & 1 & 3,33 \\
\hline Jumlah & & 30 & 100,00 \\
\hline
\end{tabular}

Sumber: Data Primer diolah, 2019

Tabel 1 menunjukkan bahwa istri nelayan memiliki tingkat pendidikan formal relatif rendah, yaitu sebagian besar responden $(56,67 \%)$ memiliki tingkat pendidikan Tamat SD dan hanya 3,33\% memiliki tingkat pendidikan formal hingga tamat SMA. Berdasarkan tingkat pendidikan formal yang dimiliki istri nelayan tersebut dapat dikatakan bahwa istri nelayan di Kecamatan Ampenan tergolong memiliki tingkat pendidikan relatif rendah. Soekartawi (1994) dalam Farih (2013) dinyatakan bahwa "masyarakat dengan tingkat pendidikan SD ke bawah masih tergolong tingkat pendidikan yang rendah".

\section{Jumlah Anggota Keluarga}

Semakin banyak jumlah anggota keluarga yang ditanggung oleh responden, maka semakin besar jumlah pengeluaran untuk biaya hidup sehari-harinya. Besarnya biaya hidup akan berdampak pada ketersediaan modal usaha berikutnya. Hasil penelitian menunjukkan bahwa rata-rata jumlah anggota keluarga responden sebanyak 4 orang dengan kisaran 3-6 orang.

Tabel 2. Sebaran Responden berdasarkan Jumlah Anggota Keluarga di Kecamatan Ampenan, Tahun 2019

\begin{tabular}{llrc}
\hline No. & $\begin{array}{c}\text { Jumlah Anggota Keluarga } \\
\text { (orang) }\end{array}$ & $\begin{array}{c}\text { Jumlah Responden } \\
\text { (orang) }\end{array}$ & $\begin{array}{c}\text { Persentase } \\
(\%)\end{array}$ \\
\hline 1 & $3-4$ & 24 & 80,00 \\
2 & $\geq 5$ & 6 & 20,00 \\
\hline & Jumlah & 30 & 100,00 \\
\hline & Rata-rata & 4 & \\
\hline
\end{tabular}

Sumber: Data Primer diolah, 2019

Jumlah anggota yang dimaksud dalam penelitian ini adalah orang yang hidup dalam satu keluarga dan satu dapur. Oleh karenanya jumlah anggota keluarga 
berpengaruh terhadap biaya yang harus ditanggung untuk dalam suatu rumah tangga. Semakin banyak jumlah anggota keluarga maka biaya yang dikeluarkan untuk hidup sehari-hari akan semakin besar. Besarnya rumah tangga keluarga ditentukan oleh jumlah anggota keluarga yang ditanggung dalam satu rumah tangga. Besar kecilnya rumah tangga dapat dikatagorikan, jika tanggungan keluarganya $3-4$ jiwa, tipe keluarga menengah dan jika tanggungan keluarganya $>4$ jiwa, tipe keluarga besar.

Hasil penelitian menunjukkan rata-rata jumlah anggota keluarga sebanyak 4 orang, berkisar 3-6 orang. Pada Tabel 2 tampak bahwa sebagian besar (80\%) responden memiliki jumlah anggota keluarga nelayan sebanyak 3-4 orang. Sisanya $20 \%$ responden memiliki jumlah anggota keluarga $\geq 5$ orang. Hal ini menunjukan bahwa rata-rata responden rumah tangga nelayan di Kecamatan Ampenan tergolong dalam keluarga menengah.

\section{Jenis Kegiatan Produktif Istri Nelayan}

Dalam suatu rumah tangga di pedesaan umumnya istri melakukan berbagai aktifitas produktif untuk membantu ekonomi rumah tangga. Berdasarkan hasil penelitian, beberapa aktifitas produktif yang dilakukan oleh istri nelayan di Kecamatan Ampenan yang lebih jelas disajikan pada Tabel 3.

Tabel 3. Jumlah Responden Berdasarkan Kegiatan Produktif Istri Nelayan di Kecamatan Ampenan, Tahun 2019

\begin{tabular}{clcc}
\hline No. & $\begin{array}{c}\text { Kegiatan Produktif } \\
\text { Perempuan Nelayan }\end{array}$ & $\begin{array}{c}\text { Jumlah Responden } \\
\text { (org) }\end{array}$ & $\begin{array}{c}\text { Persentase } \\
(\%)\end{array}$ \\
\hline 1 & Pedagang Ikan & 3 & 10,00 \\
2 & Pedagang Sembako & 1 & 3,33 \\
3 & Pedagang Serabi & 1 & 3,33 \\
4 & Pedagang Nasi & 1 & 3,33 \\
5 & Pedagang Jajan & 1 & 3,33 \\
6 & Pedagang Sayur & 1 & 3,33 \\
7 & Buruh Cuci & 2 & 6,67 \\
8 & Buruh Pindang & 4 & 13,33 \\
9 & PRT & 4 & 13,33 \\
10 & Pengasuh Anak & 1 & 3,33 \\
11 & Penjaga Toko & 1 & 3,33 \\
12 & Karyawan Loundry & 1 & 3,33 \\
13 & Tidak Bekerja & 9 & 30,00 \\
\hline & Jumlah & 30 & 100,00 \\
\hline
\end{tabular}

Sumber: Data primer diolah, Tahun 2019

Tabel 3 menunjukkan bahwa sebagian besar istri nelayan (70\%) responden bekerja untuk menambah total pendapatan rumah tangga nelayan, sisanya $30 \%$ istri nelayan tidak bekerja. Istri nelayan yang tidak bekerja (30\% responden) tersebut umumnya disebabkan karena tidak mendapat izin dari suami disebabkan karena memiliki anak usia balita.

Berdasarkan hasil penelitian (Tabel 3) diketahui bahwa terdapat beberapa jenis kegiatan ekonomi produktif istri nelayan, yaitu: terbanyak 13,33\% masing-masing bekerja sebagai buruh pemindang dan pembantu rumah tangga, responden yang 
bekerja sebagai buruh pemindang biasanya diberi pelatihan selama satu hari oleh pemilik usaha pemindangan, pekerjaan ini dipilih oleh istri nelayan lantaran pasokan ikan yang hampir selalu ada dan untuk upah buruh pemindang sendiri diberikan per hari oleh pemilik usaha tersebut yakni dengan cara menghitung berapa banyak jumlah ikan yang dipindang oleh masing-masing buruh kemudian di hargai per ekornya dan $13,33 \%$ responden yang bekerja sebagai pembantu rumah tangga (PRT) tidak memerlukan keahlian khusus karena semua pekerjaan tersebut umunya adalah kegiatan yang dilakukan sehari-hari di rumah dan sudah terbiasa dikerjakan sendiri oleh istri nelayan tak heran banyak diantaranya memilih jenis pekerjaan ini, serta $10 \%$ responden istri nelayan yang bekerja sebagai pedagang ikan hal ini lantaran istri nelayan tidak banyak membantu para suami dalam proses penjualan ikan dikarenakan ikan biasanya di jual langsung di tempat pendaratan atau langsung di jual ke TPA oleh para nelayan dan $6,67 \%$ sebagai buruh cuci pekerjaan ini dipilih karena pekerjaan sebagai buruh cuci merupakan pekerjaan yang biasa dilakukan sehari-hari oleh para istri nelayan dan pekerjaan ini tergolong tidak terikat karena pekerjaan ini bisa dilakukan di sela-sela sebagai istri. Selain itu, terdapat pula masing-masing 3,33\% istri nelayan bekerja sebagai pedagang sembako, pedagang serabi, pedagang nasi, pedagang jajan, pedagang sayur jenis pekerjaan ini tentunya sangat menjanjikan karena pekerjaan sebagai pedagang banyak memperoleh keuntungan dan mempunyai peluang untuk berkembang, pekerjaan sebagai pedagang dipilih karena tidak mengganggu tugas dan kewajiban sebagai ibu rumah tangga karena usaha yang di jalankan bertempat di rumah. Pekerjaan sebagai pedagang sangat menjanjikan karena dapat membantu menyediakan kebutuhan untuk masyarakat sekitar, dengan begitu istri nelayanpun memperoleh penghasilan tambahan untuk memenuhi kebutuhan keluarga, pengasuh anak 3,33 dipilih karena istri nelayan tidak memiliki ketarampilan lain maka istri nelayan memilih sebagai pengasuh anak saja lantaran kegiatan tersebut adalah hal yang sudah biasa dilakukan, selanjutnya, 3,33\% responden yang bekerja sebagai penjaga toko biasanya memperoleh pelatihan dan pemantuan khusus yang diberikan oleh pemilik toko selama beberapa bulan bahkan lebih karena pekerjaan ini membutuhkan ketelitian yang cukup. Tidak heran jenis pekerjaan ini sangat jarang ditemui di kalangan istri nelayan mengingat tingkat pendidikan istri nelayan yang sangatlah rendah, dan yang terakhir 3,33\% sebagai karyawan loundry, pekerjaan ini jarang di temui lantaran di sekitar daerah penelitian tidak banyak usaha yang membuka jasa loudry.

Semua jenis pekerjaan yang dilakukan istri nelayan umumnya atas dasar kemauan sendiri, maka istri nelayan berinisiatif untuk mencari peluang pekerjaan sesuai dengan bidang dan kemampuan masing-masing, tentu saja atas dasar izin dari suami mengingat kebutuhan rumah tangga yang semakin meningkat.

Jika dilihat dari pekerjaan yang dilakukan oleh istri nelayan dapat diketahui bahwa pekerjaan tersebut tidak memerlukan tingkat pendidikan yang tinggi. Jika dikaitkan dengan hasil penelitian Nilakusumawati (2017) yang menyatakan bahwa pada umumnya yang terlibat pada pekerjaan sektor informal memiliki tingkat pendidikan rendah. Dari hasil penelitian diketahui bahwa istri nelayan di Kecamatan Ampenan umumnya memiliki tingkat pendidikan formal relatif rendah, yaitu sebagian besar responden $(56,67 \%)$ memiliki tingkat pendidikan Tamat SD dan hanya 3,33\% memiliki tingkat pendidikan formal hingga tamat SMA. Berdasarkan tingkat pendidikan formal yang dimiliki istri nelayan tersebut dapat dikatakan bahwa istri nelayan di Kecamatan Ampenan tergolong memiliki tingkat pendidikan relatif rendah. 


\section{Jenis Kegiatan Produktif Suami dan Anak}

Untuk memenuhi kebutuhan ekonomi rumah tangga, umumnya semua anggota rumah tangga yang dapat bekerja (bapak, ibu, dan anak) akan membantu menopang ekonomi rumah tangga tersebut sehingga kebutuhannya dapat terpenuhi. Terdapat beberapa aktifitas produktif yang dilakukan bapak dan anak dalam rumah tangga nelayan, yaitu: melaut dan beberapa aktifitas produktif lain. Jumlah responden berdasarkan kegiatan produktif anggota rumah tangga perempuan nelayan di Kecamatan Ampenan, Tahun 2020 lebih jelas disajikan pada Tabel 4.

Tabel 4. Jumlah Responden Berdasarkan Kegiatan Produktif Suami dan Anak Nelayan di Kecamatan Ampenan, Tahun 2019

\begin{tabular}{|c|c|c|c|}
\hline No. & $\begin{array}{l}\text { Kegiatan Produktif Suami } \\
\text { dan Anak Nelayan }\end{array}$ & $\begin{array}{c}\text { Jumlah Responden } \\
\text { Rumah Tangga } \\
\text { (org) }\end{array}$ & $\begin{array}{c}\text { Persentase } \\
(\%)\end{array}$ \\
\hline \multirow[t]{5}{*}{1} & Suami: & & \\
\hline & Melaut + Ojek & 6 & 20,00 \\
\hline & Melaut + Kuli Bangunan & 3 & 10,00 \\
\hline & Melaut & 21 & 70,00 \\
\hline & Jumlah & 30 & 100,00 \\
\hline \multirow[t]{5}{*}{2} & Anak: & & \\
\hline & Pengasuh Anak & 2 & 6,67 \\
\hline & Pramusaji & 1 & 3,33 \\
\hline & Tidak Bekerja & 27 & 90,00 \\
\hline & Jumlah & 30 & 100,00 \\
\hline
\end{tabular}

Sumber: Data primer diolah, Tahun 2019

Berdasarkan hasil penelitian, pekerjaan pokok suami adalah sebagai nelayan. Adapun pekerjaan sampingan suami diantaranya adalah ojek dan kuli bangunan, sedangkan anak memilik aktivitas produktif sebagai pengasuh anak dan pramusaji. Pada Tabel 4 tampak bahwa sebagian besar suami (70\%) responden hanya mengandalkan dari pekerjaannya melaut (nelayan) untuk memenuhi kebutuhan ekonomi rumah tangganya. Semetara itu, terdapat $20 \%$ responden dimana suaminya selain melaut (nelayan) juga memanfaatkan waktu luangnya dengan bekerja sebagai pengojek. Selain itu, terdapat juga $10 \%$ responden memiliki pekerjaan atau aktivitas produktif: nelayan dan sebagai kuli bangunan. Sementara itu, hanya terdapat $10 \%$ responden memiliki anak yang bekerja, yaitu $6,67 \%$ responden yang memiliki anak bekerja sebagai pengasuh anak (baby sitter) dan 3,33\% responden memiliki anak yang bekerja sebagai pramusaji. Dari seluruh responden, sebagian besar $(90 \%)$ responden memiliki anak dalam usia sekolah atau balita sehingga (tidak bekerja).

\section{Partisipasi Istri Nelayan Pada Kegiatan Ekonomi Produktif}

Dalam kehidupan keseharian nelayan, istri nelayan berperan penting dalam meningkatkan ekonomi rumah tangga. Istri nelayan dapat berperan ganda, baik sebagai ibu rumah tangga maupun sebagai pekerja untuk memperoleh penghasilan tambahan agar kebutuhan keluarga tercukupi tentunya sesuai dengan keterampilan yang dimiliki. Ketimpangan pada akses produktif yang ada pada masyarakat membuat 
istri nelayan sukar meningkatkan kemampuan mereka untuk berkontribusi dan mengembangkan potensi secara maksimal.

Akses terhadap informasi, pemanfaatan sumberdaya alam, pendidikan, fasilitas kredit, dan hak untuk mengemukakan pendapat merupakan unsur-unsur yang perlu diperjuangkan guna keluar dari ketimpangan yang ada. Kondisi ini menunjukkan bahwa peranan istri nelayan sebagai pelaku ekonomi tidak boleh diabaikan, bahkan diperlukan dukungan teknologi untuk menunjang dalam kegiatan sosial dan ekonomi agar istri nelayan dapat mengalokasikan waktunya lebih banyak pada kegiatan produktif tanpa meninggalkan peran domestiknya. Sementara itu, partisipasi perempuan istri nelayan dalam penellitian ini berarti pengambilan bagian atau pengikutsertaan dalam kegiatan produktif sehingga dapat memberi sumbangan terutama pada ekonomi rumah tangga. Rata-rata akses dan partisipasi istri nelayan di Kecamatan Ampenan disajikan pada Tabel 5.

Tabel 5. Rata-rata Akses dan Partisipasi Istri Nelayan di Kecamatan Ampenan, Tahun 2019

\begin{tabular}{|c|c|c|c|c|c|}
\hline \multirow[b]{2}{*}{ No. } & \multirow{2}{*}{$\begin{array}{c}\text { Akses dan } \\
\text { Partisipasi Istri } \\
\text { Nelayan }\end{array}$} & \multicolumn{2}{|c|}{ Akses } & \multicolumn{2}{|c|}{ Partisipasi } \\
\hline & & $\begin{array}{c}\text { Jumlah } \\
\text { (org) }\end{array}$ & $\begin{array}{c}\text { Persen } \\
(\%)\end{array}$ & $\begin{array}{l}(\mathrm{HKO} / \\
\text { tahun })\end{array}$ & $(\%)$ \\
\hline 1 & Bekerja & 21 & 70 & 261,31 & 71,59 \\
\hline 2 & Tidak Bekerja & 9 & 30 & 0 & 0,00 \\
\hline & Jumlah & 30 & 100 & 261,31 & 71.59 \\
\hline
\end{tabular}

Sumber: Data primer diolah, Tahun 2019

Tabel 5 menunjukkan bahwa dari seluruh responden, sebagian besar (70\%) responden (istri nelayan) memiliki akses untuk memanfaatkan peluang bekerja pada aktivitas ekonomi produktif, sedangkan (30\%) lainnya tidak bekerja. Beberapa jenis aktivitas ekonomi produktif yang dilakukan istri nelayan pada umumnya sebagai pedagang ikan dan bersifat informal. Pekerjaan yang di lakukan meliputi: pedagang ikan, pedagang sembako, serabi, nasi, jajan, dan pedagang sayuran. Selain itu terdapat istri nelayan yang bekerja sebagai buruh cuci, buruh pemindangan, pembantu rumah tangga, pengasuh anak, penjaga toko, dan karyawan loundry. Kegiatan pekerjaan yang dipilih oleh istri nelayan tidak terikat. Pekerjaan informal yang dilakukan oleh para istri nelayan merupakan pekerjaan yang diciptakan sendiri, pekerjaan ini tidak tergantung pada pihak lain sehingga waktu kerjapun tidak terikat.

Berdasarkan hasil wawancara diketahui bahwa pada dasarnya, istri nelayan di lokasi penelitian umumnya memiliki akses untuk bekerja dalam rangka menambah total pendapatan rumah tangga. Istri nelayan yang tidak bekerja (30\% responden). Hal ini disebabkan karena masih memiliki anak usia balita sehingga para istri nelayan harus menjaga anaknya, disamping itu para istri nelayan juga tidak mendapatkan izin dari suami untuk bekerja hal ini karena para suami mengharapkan istrinya agar fokus mengurusi rumah tangga. Selanjutnya, partisipasi istri nelayan dalam penelitian ini berarti pengambilan bagian atau keikutsertaan dalam kegiatan produktif sehingga dapat memberi sumbangan terutama pada ekonomi rumah tangga. Pada Tabel 4.8 tampak bahwa partisipasi istri nelayan meluangkan waktunya untuk bekerja sebanyak 261,31 HKO dalam setahun. Artinya, dari 365 hari dalam setahun dengan jam kerja 7 jam per hari (365 HKO), istri nelayan memanfaatkan waktunya untuk berpartisipasi 
bekerja selama 261 hari atau 71,59\% setahun untuk menambah total pendapatan rumah tangga.

Dari hasil penelitian, terdapat 3 (tiga) kelompok responden berdasarkan anggota rumah tangga yang memiliki akses bekerja dan memberikan kontribusinya bagi pendapatan rumah tangga nelayan, yaitu:

1) Semua anggota rumah tangga (bapak, ibu dan anak) berpartispasi bekerja.

2) Bapak dan ibu yang berpartisipasi bekerja.

3) Hanya bapak yang bekerja.

Rata-rata akses dan partisipasi istri nelayan serta semua anggota rumah tangga nelayan di Kecamatan Ampenan, Tahun 2020 disajikan pada Tabel 6.

Tabel 6. Rata-rata Partisipasi Istri Nelayan serta Semua Anggota Rumah Tangga Nelayan di Kecamatan Ampenan, Tahun 2019

\begin{tabular}{|c|c|c|c|c|c|c|c|c|c|}
\hline \multirow{3}{*}{ No. } & \multirow{3}{*}{ Uraian } & \multirow{3}{*}{$\begin{array}{l}\text { Jml } \\
\text { Resp. } \\
\text { (org) }\end{array}$} & \multicolumn{6}{|c|}{ Partisipasi Istri Nelayan } & \multirow{3}{*}{$\begin{array}{c}\text { Total } \\
\text { Pndptn } \\
\text { RT } \\
\text { (Rp/th) }\end{array}$} \\
\hline & & & \multicolumn{2}{|r|}{ Bapak } & \multicolumn{2}{|c|}{ Ibu } & \multicolumn{2}{|c|}{ Anak } & \\
\hline & & & $\begin{array}{l}\text { HKO } \\
\text { per th }\end{array}$ & $\begin{array}{l}\text { Pndptn } \\
(\mathrm{Rp} / \mathrm{th})\end{array}$ & $\begin{array}{l}\text { HKO } \\
\text { per th }\end{array}$ & $\begin{array}{l}\text { Pndptn } \\
\text { (Rp/th) }\end{array}$ & $\begin{array}{l}\text { HKO } \\
\text { per th }\end{array}$ & $\begin{array}{l}\text { Pndptn } \\
\text { (Rp/th) }\end{array}$ & \\
\hline 1 & Bapak+Ibu+Anak & 3 & 228 & 129.297 .167 & 206 & 15.120 .000 & 312 & 9.880 .000 & 154.297 .167 \\
\hline 2 & Bapak + Ibu & 18 & 269 & 150.523 .655 & 271 & 17.646 .667 & 0 & 0 & 168.170 .322 \\
\hline 3 & Bapak & 9 & 263 & 165.503 .625 & 0 & 0 & 0 & 0 & 165.503 .625 \\
\hline
\end{tabular}

Sumber: Data primer diolah, Tahun 2019

Tabel 6 tampak bahwa sebagian besar responden (18 responden) atau 60\% dari seluruh responden yang berpartisipasi dan memiliki akses bekerja adalah bapak dan ibu. Sementara itu, terdapat 3 orang responden (10\%) dimana semua anggota rumah tangga (bapak, ibu dan anak) memiliki akses dan pertisipasi pada kegiatan ekonomi produktif, sisanya (30\%) responden hanya bapak yang memiliki akses dan partisipasi dalam kegiatan ekonomi produktif rumah tangga nelayan.

Dari Tabel 6 pada rumah tangga nelayan dimana bapak, ibu dan anak memiliki akses dan partisipasi untuk bekerja dan menghasilkan pendapatan diperoleh rata-rata total pendapatan rumah tangga sebesar Rp 154.297.167 per tahun dimana istri nelayan (ibu) memiliki akses bekerja sebanyak 206 HKO per tahun dengan partisipasi pendapatan sebesar Rp 15.120.000 terhadap total pendapatan rumah tangga.

Untuk responden dimana bapak dan ibu yang memiliki akses dan partisipasi terhadap ekonomi rumah tangga nelayan, diperoleh rata-rata pendapatan rumah tangga sebesar Rp 168.170.322 per tahun. Adapun partisipasi istri nelayan terhadap pendapatan rumah tangga adalah Rp 17.646.667 per tahun dengan akses rata-rata 271 HKO per tahun. Sementara itu, bapak memberikan partisipasinya terhadap pendapatan rumah tangga $\mathrm{Rp}$ 150.523.655 per tahun.

Selanjutnya untuk rumah tangga nelayan dimana hanya bapak yang memiliki akses dan partisipasi bekerja memberikan pendapatan Rp 165.503.625 per tahun.

Apabila dilihat dari total pendapatan rumah tangga dari 3 (tiga) kelompok responden (Tabel 6) tampak bahwa rata-rata pendapatan rumah tangga yang terbesar adalah pada responden dimana hanya bapak dan ibu yang bekerja, yaitu sebesar Rp 168.170.322 per tahun lebih besar dibandingkan dua kelompok lainnya. Sementara itu, kelompok responden ketiga memiliki rata-rata pendapatan rumah tangga sebesar Rp 165.503.625 per tahun lebih besar dibandingkan dengan kelompok responden pertama 
dimana semua anggota keluarga (bapak+ibu+anak) bekerja dengan rata-rata pendapatan rumah tangga Rp 154.297.167 per tahun.

Dalam kasus di atas, terlihat bahwa kelompok responden ketiga dimana hanya bapak yang bekerja dan memiliki rata-rata pendapatan rumah tangga lebih tinggi dibandingkan dengan kelompok responden pertama (bapak+ibu+anak) bekerja. Hal ini disebabkan, pendapatan bapak pada kelompok responden pertama relatif lebih kecil dibandingkan pendapatan bapak pada kelompok responden ketiga. Selain itu, pendapatan bapak pada kelompok responden pertama hanya bersumber dari pekerjaan nelayan saja tanpa pekerjaan sampingan. Oleh karena itu, ibu dan anak turut berpartisipasi (bekerja) untuk menambah total pendapatan rumah tangga. Sementara itu pada kelompok responden kedua dan ketiga, suami (bapak) selain bekerja sebagai nelayan, juga melakukan pekerjaan sampingan seperti: ojek dan buruh bangunan pada saat tidak melaut sehingga suami dapat memberikan pendapatan lebih besar dibandingkan kelompok responden pertama (tanpa pekerjaan sampingan). Rata-rata pendapatan suami (bapak) dari aktivitas ekonomi produktif berdasarkan kelompok responden disajikan pada Tabel 7.

Tabel 7. Rata-rata Pendapatan Suami Bersumber dari Nelayan dan Sampingan di Kecamatan Ampenan, Tahun 2019

\begin{tabular}{|c|c|c|c|c|c|c|}
\hline \multirow{2}{*}{ No. } & \multirow{2}{*}{ Uraian } & \multirow{2}{*}{$\begin{array}{l}\text { Jml } \\
\text { Resp. } \\
\text { (org) }\end{array}$} & \multicolumn{3}{|c|}{ Pendapatan Suami } & \multirow{2}{*}{$\begin{array}{l}\text { Total } \\
\text { Suami } \\
\text { (Rp/th) }\end{array}$} \\
\hline & & & $\begin{array}{c}\text { Melaut } \\
(\mathrm{Rp} / \mathrm{th})\end{array}$ & $\begin{array}{c}\text { Ojek } \\
(\mathrm{Rp} / \mathrm{th})\end{array}$ & $\begin{array}{c}\text { Kuli Bngn } \\
\text { (Rp/th) }\end{array}$ & \\
\hline 1 & Bapak+Ibu+Anak & 3 & 129297167 & 0 & 0 & 129297167 \\
\hline 2 & Bapak + Ibu & 18 & 148712788 & 1010867 & 800000 & 150523655 \\
\hline 3 & Bapak & 9 & 163768492 & 951800 & 783333 & 165503625 \\
\hline
\end{tabular}

Sumber: Data primer diolah, Tahun 2019

Tabel 7 tampak bahwa kelompok responden kedua dan ketiga, suami memiliki pekerjaan sampingan, yaitu ojek dan kuli bangunan, sedangkan pada kelompok responden pertama suami hanya bekerja sebagai nelayan saja tanpa pekerjaan sampingan sehingga total pendapatan suami pada kelompok responden pertama lebih kecil dibandingkan kelompok responden kedua dan ketiga. Lebih lanjut, apabila dilihat pendapatan suami yang bersumber dari nelayan pada kelompok responden pertama relatif lebih kecil dibandingkan dengan kelompokn responden kedua dan ketiga. Hal ini karena pada kelompok responden pertama memiliki sampan lebih kecil sehingga mempengaruhi hasil tangkapan yang pada akhinya pendapatan dari melaut juga lebih sedikit.

\section{Kontribusi Istri Nelayan Terhadap Pendapatan Rumah Tangga}

Dalam ekonomi rumah tangga seperti halnya rumah tangga nelayan, total pendapatan rumah tangga umumnya bersumber dari berbagai aktivitas produktif yang dilakukan oleh semua anggota rumah tangga yang dapat bekerja, baik dari bapak, istri, maupun anaknya. Masing-masing anggota rumah tangga tentu memberikan kontribusinya terhadap total pendapatan rumah tangga.

Berdasarkan hasil penelitian terhadap rumah tangga nelayan di Kecamatan Ampenan, diperoleh tiga kelompok responden berdasarkan anggota rumah tangga yang bekerja pada kegiatan ekonomi produktif. Kelompok pertama (3 responden) 
semua anggota rumah tangga (bapak, ibu dan anak) memiliki kontribusi terhadap total pendapatan rumah tangga. Kelompok kedua (18 responden) hanya bapak dan ibu yang bekerja pada kegiatan ekonomi produktif sehingga hanya bapak dan ibu yang memberikan kontribusi terhadap total pendapatan rumah tangga. Kelompok ketiga ( 9 responden) hanya bapak yang bekerja pada kegiatan ekonomi produktif rumah tangga, sehingga pada kelompok ketiga ini tidak ada kontribusi pendapatan dari istri dan anaknya.

Rata-rata kontribusi pendapatan istri nelayan dan semua anggota rumah tangga yang bekerja terhadap total pendapatan rumah tangga nelayan di Kecamatan Ampenan, Tahun 2020 disajikan pada Tabel 8.

Tabel 8. Rata-rata Kontribusi Pendapatan Istri Nelayan Terhadap Pendapatan Rumah Tangga Nelayan di Kecamatan Ampenan, Tahun 2019

\begin{tabular}{|c|c|c|c|c|c|c|c|c|c|c|}
\hline \multirow{3}{*}{ No. } & \multirow{3}{*}{ Uraian } & \multirow{3}{*}{$\begin{array}{l}\text { Jml } \\
\text { Resp. } \\
\text { (org) }\end{array}$} & \multicolumn{6}{|c|}{ Hari Kerja dan Kontribusi Pendapatan } & \multicolumn{2}{|l|}{ Total } \\
\hline & & & \multicolumn{2}{|c|}{ Bapak } & \multicolumn{2}{|c|}{ Ibu } & \multicolumn{2}{|c|}{ Anak } & \multirow{2}{*}{$\begin{array}{c}\text { Pendapatan } \\
\text { RT } \\
\text { (Rp) }\end{array}$} & \multirow{2}{*}{$\begin{array}{l}\text { Persen } \\
(\%)\end{array}$} \\
\hline & & & $\begin{array}{l}\text { Pndptn } \\
\text { (Rp/th) }\end{array}$ & $\begin{array}{c}\text { Persen } \\
(\%)\end{array}$ & $\begin{array}{l}\text { Pndptn } \\
\text { (Rp/th) }\end{array}$ & $\begin{array}{c}\text { Persen } \\
(\%)\end{array}$ & $\begin{array}{l}\text { Pndptn } \\
\text { (Rp/th) }\end{array}$ & $\begin{array}{c}\text { Pesen } \\
(\%)\end{array}$ & & \\
\hline 1 & Bapak+Ibu+Anak & 3 & 129.297.167 & 83,80 & 15.120 .000 & 9,80 & 9.880 .000 & 6,40 & 154.297.167 & 100,00 \\
\hline 2 & Bapak + Ibu & 18 & 150.523 .655 & 89,51 & 17.646 .667 & 10,49 & 0 & 0,00 & 168.170 .322 & 100,00 \\
\hline \multirow[t]{2}{*}{ J } & Bapak & 9 & 165.503 .625 & 100,00 & 0 & 0,00 & 0 & 0,00 & 165.503 .625 & 100,00 \\
\hline & Rata-rata & & 148.441 .482 & 91,26 & 10.922 .222 & 6,72 & 9.880 .000 & 2,02 & 162.657 .038 & 100,00 \\
\hline
\end{tabular}

Sumber: Data primer diolah, Tahun 2019

Tabel 8 tampak bahwa rata-rata pendapatan rumah tangga nelayan di Kecamatan Ampenan adalah Rp 162.657.038 per tahun. Dari total pendapatan rumah tangga tersebut, rata-rata kontribusi pendapatan istri adalah 6,72 persen dari total pendapatan rumah tangga. Sebagian besar total pendapatan rumah tangga $(91,26 \%)$ merupakan kontribusi pendapatan suami dari pekerjaan nelayan dan pekerjaan sampingan. Sisanya 2,02\% merupakan kontribusi pendapatan anak.

Berdasarkan kelompok responden, pada Tabel 8 menunjukkan bahwa total pendapatan rumah tangga pada kelompok responden pertama dimana yang bekerja pada kegiatan ekonomi produktif adalah bapak, ibu dan anak adalah Rp 154.297.167 per tahun. Dari total pendapatan rumah tangga tersebut, kontribusi perempuan (istri) nelayan sebesar Rp 15.120.000 per tahun atau 9,80\% terhadap total pendaptan rumah tangga. Sementara itu, bapak (suami) memberkan kontribusi terbesar $(83,80 \%)$ terhadap total pendatan rumah tangga, sementara anak memberi kontribusi 6,40\%.

Selanjutnya, rata-rata pendapatan rumah tangga pada kelompok responden kedua dimana yang bekerja pada kegiatan ekonomi produktif hanya bapak dan ibu saja adalah Rp 168.170.322 per tahun. Adapun kontribusi istri nelayan adalah Rp 17.646.667 per tahun atau memberi kontribusi $10,49 \%$ terhadap total pendapatan rumah tangga. Demikian juga halnya pada kelompok responden kedua ini, bapak memberikan kontribusi terbesar $(89,51 \%)$ terhadap total pendapatan rumah tangga nelayan.

Pada kelompok responden ketiga, rata-rata pendapatan rumah tangga nelayan adalah Rp 165.503.625 per tahun, dimana pada kelompok ketiga ini anggota rumah tangga yang bekerja pada kegiatan ekonomi produktif hanya suami atau bapak, sedangkan ibu dan anak tidak bekerja. Hal ini berarti 100\% pendapatan rumah tangga nelayan adalah kontribusi dari bapak. Berdasarkan hasi penelitian, istri nelayan pada 
kelompok responden ketiga ini tidak bekerja disebabkan karena tidak mendapat izin dari suami dan mempunyai anak yang masi balita sehingga tidak memiliki akses untuk bekerja pada kegiatan ekonomi produktif. Di lain pihak, pendapatan yang diperoleh bapak (suami) dirasakan dapat memenuhi kebutuhan ekonomi rumah tangganya.

\section{KESIMPULAN DAN SARAN}

\section{Kesimpulan}

1) Jenis kegiatan ekonomi produktif yang dilakukan istri nelayan meliputi: pedagang ikan $(10,00)$, sembako $(3,33)$, serabi $(3,33)$, nasi $(3,33)$, jajan $(3,33)$, pedagang sayur $(3,33)$, buruh cuci $(6,67)$, buruh pindang $(13,33)$, pembantu rumah tangga $(13,33)$, pengasuh anak $(3,33)$, penjaga toko $(3,33)$, dan karyawan loundry $(3,33)$. Pekerjaan ekonomi produktif suami meliputi: nelayan, ojek dan buruh bangunan, sedangkan anak bekerja sebagai pengasuh anak (baby sitter) dan pramusaji.

2) Istri nelayan di Kecamatan Ampenan yang memiliki akses untuk memanfaatkan peluang bekerja pada kegiatan ekonomi produktif sebanyak $70 \%$ dengan rata-rata partisipasi sebesar 261,31 HKO (71,75\%) per tahun, sedangkan 30\% lainnya tidak memiliki akses bekerja.

3) Kontribusi pendapatan suami dari pekerjaan nelayan dan pekerjaan sampingan 91,26\%, dan sisanya 2,02 \% merupakan kontribusi pendapatan anak sedangkan pendapatan rata-rata rumah tangga nelayan di Kecamatan Ampenan sebesar Rp 162.657.038 per tahun dengan rata-rata kontribusi pendapatan istri sebesar 6,72\% dari pendapatan rumah tangga.

\section{Saran}

1) Untuk meningkatkan pendapatan istri nelayan khususnya di Kecamatan Ampenan disarankan kepada pemerintah melalui satuan kerja terkait sehingga dapat meningkatkan akses istri nelayan pada berbagai kegiatan ekonomi produktif.

2) Bagi istri nelayan yang tidak bekerja disarankan agar memanfaatkan waktu luang dirumah untuk melakukan kegiatan ekonomi produktif. 


\section{DAFTAR PUSTAKA}

Anonim, 2013. Gambaran Rumah Tangga Nelayan.http://www.kompasiana.com/ arisarmunanto8970/5b7e6dc4677ffb20c53aeba2/memori-indah-di-kampungnelayan. [25 Desember 2018].

Anonim, 2016. Pengertian Akses.http//www.pengertianmenurutparaahli.net/pengertian-akses/. [26 Agustus 2019].

Anonim, 2016. Peran Ganda.https://naadanar.wordpress.com/2012/03/31/apa-ituperan-ganda/. [26 Agustus 2019].

Belante, 1983. Teori Alokasi Waktu Kerja. repository.unhas.ac.id. [23 Desember 2018].

BPS-Statistik Indonesia, 2020. Badan Pusat Statistik Indonesia. https://www.bps.go.id/istilah/index.html?Istilah_page=4

Dinas Kelautan dan Perikanan Lombok Barat, 2010. Rincian Tekhnik Pembuatan Garam di Kabupaten Lombok Barat Tahun 201. Mataram.

Handayani, Sri. 2007. Partisipasi Wanita Tani dalam Kegiatan Usaha Tani Tembakau Virginia Fc di Kecamatan Sakra Barat Kabupaten Lombok Timur. Fakultas Pertanian Universitas Mataram.

Kay, Alder. 1999. Pengertian Wilayah Pesisir. http://studio6timbulsloko. wordpress.com. [23 Desember 2018].

Nazir. 2005. Metode Penelitian. Ghalia Indonesia. Bogor.

Ndaraha, Talizidulu. 1990. Pembangunan Masyarakat. "Manajement Masyarakat Tidak Landas. "Rineka Cipta. Jakarta.

Shlager and Ostrom, 1992. http://www.sciRporg

Soetrisno, 1997. Peran Ganda Istri Nelayan. Ghalia Indonesia. Bogor.

Wulan. 2011. Peran Ganda Perempuan. http://mbaawoeland.blogspot.com/ 2011/12/peran-ganda-perempuan.html 